\title{
Comparative analysis on HIV patient survival in Arad county
}

\author{
Laura Nicolescu ${ }^{1 *}$, Dana Negru', Teodora Olaru², Mirandolina Prişcă² \\ From The 7th Romanian National HIV/AIDS Congress and The 2nd Central European HIV Forum \\ Sibiu, Romania. 29-31 May 2014
}

Survival for HIV patients has considerably improved after the introduction of antiretroviral therapy, viral resistance, co-infections and intercurrent infections monitoring.

We have analyzed HIV registered cases between 19902013, starting from the hypothesis that the median survival of patients in the absence of antiretroviral therapy could be only five years, for the first decade of the period under review. Data were analyzed with SPSS.14.0 for Windows and MedCalc.

HIV infection in Arad recorded an incidence comparable to the national average, with a ratio of 2.62 deaths for cases diagnosed in 1990-2000 compared with the period 2001-2013, with death rates of 33\% for the first period and $18 \%$ for the second. The trend of new cases is slightly decreasing but the death rates remain high. Using methods for risk of death or disease progression measuring, Kaplan-Meier Survival Curve indicates a 4 years (P $<0.0001$ ) median survival for HIV patients diagnosed between 1990-2000, with a statistically significant distribution of deaths in males $(\mathrm{P}=0.0066)$, with relative risk of death for 1990-2000 decade compared to 2001-2013, ranging from 1.5464 (95\% CI 1.094 to 2.1859). It still remains an increased risk of death for males versus females 1.3065 ( $\mathrm{P}=0.0125$ 95\% CI 0.9391 to 1.8175 ).

Antiretroviral therapy reduced the relative risk of death in HIV patients, death rates which are still increased for males.

\section{Authors' details}

${ }^{1}$ Public Health Department, Arad, Romania. ${ }^{2}$ Arad County Emergency

Hospital, Arad, Romania.

Published: 29 May 2014

${ }^{1}$ Public Health Department, Arad, Romania

Full list of author information is available at the end of the article
doi:10.1186/1471-2334-14-S4-P19

Cite this article as: Nicolescu et al:: Comparative analysis on HIV patient survival in Arad county. BMC Infectious Diseases 2014 14(Suppl 4):P19.
Submit your next manuscript to BioMed Central and take full advantage of:

- Convenient online submission

- Thorough peer review

- No space constraints or color figure charges

- Immediate publication on acceptance

- Inclusion in PubMed, CAS, Scopus and Google Scholar

- Research which is freely available for redistribution

Submit your manuscript at www.biomedcentral.com/submit
() Biomed Central
C Biomed Central

(c) 2014 Nicolescu et al; licensee BioMed Central Ltd. This is an Open Access article distributed under the terms of the Creative Commons Attribution License (http://creativecommons.org/licenses/by/4.0), which permits unrestricted use, distribution, and reproduction in any medium, provided the original work is properly cited. The Creative Commons Public Domain Dedication waiver (http://creativecommons.org/publicdomain/zero/1.0/) applies to the data made available in this article, unless otherwise stated. 